\title{
VIDES AIZSARDZĪBAS MĀCĪBU PRAKSES LABORATORIJA TOP ZEMNIEKU SAIMNIECĪBĀ “ALEKSANDRI" (z/s A)
}

\author{
JĀNIS ALNIS \\ "EKO - LUDZA" vadītäjs \\ Rundānos, Ludzas raj., Latvija, LV - 5739
}

Laboratorija bijušãs Runđānu muižas teritorijā - vietā, kurā jaunieši iepazīsies ar daudziem Latgales pakalnu, purvu vides aizsardzibas un izmantošanas praktiskiem un teorētiskiem darbiem. Izmitināšana, ēdināšana, atpūta ar rundāniešu pamestības noskaņu pärvarēšanu. Iesäkums krievvalodĩgo zonas atdzimšanai ...

Laboratorijas ideju pamatā in profesoru G.Novika, A.Ūbel̦a, M.Oša u.c. koncepcijas par vidi kā antropogēnu procesu kompleksu, kopu, ieskaitot tajos etniskos un religiskos faktorus. Izmantotas etnoekologiskās "Eko - Ludzas" zinātniskās grupas atziņas. Ora et labora! - no latīnu valodas var iztulkot, ka oratoram ir jāstrādā, ka vides aizsardzỉbai nepieciešama trīsvienība Dievs - Daba - Darbs.

Laboratorijas vieta Rundānu pagasts - vēsturē reti minēts, jo atrodas pa vidu starp Zilupi, Dagdu, Rēzekni, Ludzu, Nirzu. Z/s A izvietota Latgales augstienes üdensšķirtnē. Vides tīrības etalons. Te savu tecējumu sāk Sarjanka - Daugavas pieteka. Rundānu strauts aiznes ūdeņus uz Velikajas upi. Te pēdējā laikā seno latgalı pilskalnu aizsardzibas līnija.

10 gadus z/s A nelieto ķimikālijas. Atkritumus uzkrāj bedrēs, virs kurām iestāđa kokus. Tiek mūsdienīgi atjaunota seno latgalu naturālā saimniekošana kā videi draudziga, bet ievērojot tirgus prasības.

Laboratorijā pārstāvētas tēmas: 1) zāḷmēslojumu, sapropeļa un kūtsmēslu kombinācijas tīrumos, dārzā, mežā; 2) laistǐšana ar paštecēšanu; 3) auglu un ogu pārstrāde biezeņos, sulās un vīnā, neizmantojot tehniku; 4) kḷavu sulu pārstrāde maizes zupas koncentrātā (dziedniecībai); 5) cukurbiešu sīrupa izgatavošana bez biešu piegaršas; 6) latgalu biškopïbas restaurěšana: bišu spieta vadīšana ar sitieniem pa zāli un spaini, medus sviede - kasete uz mieta utt.

Laboratorijā izstrādātas vairākas tēmas: koku vainagu veidošana pēc ornamenta "Austras koks" likumībām; dekoratîvu koku audzēšana un veidošana meža kopšanas darbos un ornamentētos apstādījumos; laukakmeṇu dekoratīvie pielietojumi. etnogrāfiskais lauku māju remonts, izmantojot jumta skaidu, dẹlu un brusu izgatavošanas iekārtas, blietētā māla būves, fundamenti, tiltu balsti ar cementa apmetumu, siltummezgls nogāzēs lejā ar siltumvadu tranšejā uz kalti, uz kūpinātavu, siltumnīcu, šķ̄uni, izvietotiem augšup pa nogāzi; mazmuižiņas ar AEA un nolaižamiem zivju dīķiem projekts pēc Rīgas VU "Meliorprojekts"; sadarbỉba ar bebriem.

Pasākumu izstrāde, lai tiktu pārtraukta cilvēku skaita samazināšanās laukos, tīrumu un ainavu degradācija. Izstrādāts integrālais vides kvalitātes superpozīciju kritērijs kā akad. E.Lavendela u.c. ideju alternativa un kā katra praktikanta uzkrātās informācijas pārbaudes metode. 